\title{
Pergeseran Desain Komunikasi di Media Sosial
}

\author{
Nanang Arianto \\ Dosen STAIN Mandailing Natal \\ Email: nanangarianto61@yahoo.com
}

\begin{abstract}
ABSTRAK
Perkembangan komunikasi yang terjadi di media sosial sangatlah kompleks. tidak dipungkiri lagi, bahwa rekayasa sosial yang terjadi ditengah-tangah masyarakat banyak disebabkan oleh faktor media sosial. Penelitian ini mengangkat tentang pergeseran jejaring sosial yang bukan sekedar menginformasikan banyak hal, namun bisa juga untuk kepentingan tertentu seperti memobilisasi massa. Ia bergeser menjadi tidak produktif dihadapan masyarakat. Dengan menggunakan penelitian kualitatif, pendekatan kajian isi dengan fokus kajian media sosial facebook, whatsapp, twitter dan instagram. Menggunakan teori komunikasi jarum suntik, peneliti ingin menyampaikan ada beberapa pergeseran desain komunikasi melalui media sosial.
\end{abstract}

\section{Kata kunci: Desain Komunikasi; Sosial Media}

\section{PENDAHULUAN}

Media sosial, sesuai dengan namanya adalah jejaring yang melibatkan aktivitas orang banyak (Many people). Ia telah banyak melampaui fungsi utamannya sebagai media (perantara/ penghubung) namun mampu mempengaruhi bahkan menentukan sikap atau prilaku penggunanya. Ide dan gagasan baru juga banyak disebarkan di sosial media yang dirasakan sangat membantu bagi kehidupan manusia. Bahkan isi beritanya terkadang update dan actual di banding dengan media mainsream lainnya. Tak dipungkiri juga , bahwa dalam desain komunikasi kekinian jejaring sosial (media sosial) telah berkembang menjadi new media (media baru). Sebagai sebuah media atau perantara, media sosial diyakini sangat ampuh dalam memengaruhi pola pikir dan sikap masyarakat. ${ }^{1}$ Sebagaimana pendapat Marshall (pencetus media klasik) yang tidak lain adalah (the extension of man), Artinya media sosial adalah perantara manusia untuk mengekspresikan diri dan menyebarkannya.

Selanjutnya jejaring sosial memberikan banyak manfaat dan efek perubahan bagi manusia. Sebaliknya ia juga telah membuat privacy manusia terganggu, karena hampir seluruh kegiatan atau aktivitas pengguna sosial media bisa terdeteksi oleh lingkungan sekitarnya. Maka era teknologi menjadikan privacy manusia menjadi tanpa batas. Maka media sosial hari ini telah banyak mengubah pola komunikasi. Salah satunya adalah desain cara berhubungan sosial. Desain tersebut bisa lewat alat komunikasi berjejaring internet seperti facebook, instagram,twitter, dan jejaring sosial yang lain.

\footnotetext{
${ }^{1}$ Stephan W littejohn, Teori Komunikasi, (Jakarta: Salemba Humanika, 2011), Hlm.110
} 
Banyak motif manusia merencanakan agendanya, maka ia harus mendesain pesan tersebut menjadi menarik. Agar bisa diterima oleh masyarakat yang sudah terhubung melalui gadget canggihnya dalam aplikasi media sosial. Ini menjadi menarik untuk diteliti, karena desain komunikasi di media sosial sudah banyak digunakan masyarakat. Bentuk desainnya terencana oleh para pemilik akun dengan kepentingannya masing-masing. Karena kebebasan menggunakan arena publik seperti saat ini, berbagai kelompok masyarakat dapat menentukan pilihanpilihannya, sehingga kehidupan demokrasi di masyarakat berjalan dengan lebih baik. Menjadi menarik lagi arena public yang bebas (public sphere) dapat diwujudkan melalui media sosial yang diangkat kepermukaan sebagai pendapat publik (public opinion).

\section{TEORI DAN METODE PENELITIAN}

Metode penelitian yang digunanakan bersifat kualitatif, dengan pendekatan analisis isi (content analysis) dan dokumentasi perpustakaan. Fraenkel, Wallen berpendapat bahwa content analysis merupakan teknik yang dapat dipergunakan seorang penulis dalam rangka menganalisa komunikasi audien yang secara tidak langsung dapat menentukan prilaku komunikan. ${ }^{2}$ Melalui metode penelitian ini penulis mencoba menyajikan informasi yang up to date sehingga menghasilkan data penelitian yang dapat menggambarkan terjadinya pergeseran desain komunikasi di media sosial.

Secara etimologi media didefenisikan sebagai perantara dalam rangka berkomunikasi antara komunikator dengan komunikan ${ }^{3}$. Selanjutnya istilah sosial dimaknai bahwa setiap individu memberikan kontribusi dalam kehidupan sosialnya, yang memungkinkan adanya aksi yang mempengaruhi lingkungannya. Melalui defenisi diatas, dapat kita tarik kesimpulan bahwa sosial media itu adalah alat yang digunakan untuk bersosialisasi dengan jejaring sosial dan dalam lingkup sosial yang lebih luas. Sosial media ialah jaringan yang berbasis website yang memungkinkan manusia untuk berinteraksi dalam komunitas sosialnya. Andreas Caplan dan Michael Henlein mendefenisikan jejaring sosial media "adalah aplikasi yang memungkinkan pertukaran dan penciptaan user generated content berbasis internet yang dibangun atas dasar ideologi dan teknologi Web 2.0". 4

Pertukaran informasi dapat lebih luas dan cepat melalui melalui media ini, pada media sosial memungkinkan terjadi kolaborasi, perkenalan dalam berbagai desain komunikasi. Misalnya seperti: whatsapp, facebook, instagram dan lainnya. ${ }^{5}$

\footnotetext{
${ }^{2}$ Fraenkel and Wallen, how to disign and evaluate research in education, (New York: Mc Graw Hill, 2007), hlm. 483

${ }^{3}$ McQuail, D, teori komunikasi massa, (Jakarta: Penerbit Erlangga, 2003), hlm. 52

${ }^{4}$ Michael Haenlein dan Andreas Kaplan, User of the world, unite! Tehe challenges and oppurtunities of social media, (Bussiness Horrizons, 2010), hlm. 59

${ }^{5}$ Danis Puntoadi, Menciptakan penjualan melalui sosial media, (Jakarta: PT. Elex Media Computindo, 2011), hlm.1
} 
Perkembangan pesan yang tidak terdesain (pesan liar) sebagaimana yang terjadi di media sosial sepertinya berhubungan sekali dengan teori klasik jarum hipodemik (hypodermic teory). Pada era klasik dimana media juga masih sangat sederhana, Teori ini sangat populer dan agaknya relevan dengan kasus ini. Teori jarum suntik sebagaimana pernyataan Anne dan Jason bahwa efek langsung dari pesan yang disuntikkan kepada audien. ${ }^{6}$ Apapun berita atau informasi yang tersiarkan dari jejaring sosial secara langsung diadopsi masyarakat (pengguna media) tanpa tabayun (check and rechek).

Terjadinya pergeseran desain komunikasi di media sosial, diasumsikan karena pengguna media yang belum memahami fungsi dari jejaring sosial sebagai media sosialisai. Kemudian ada juga memang sengaja didesain secara masif dan terstruktur untuk kepentingan tertentu dan secara praktis mengambil keuntungan dari penggunaan media sosial tersebut, tanpa mengindahkan dampak negatifnya bagi masyarakat luas.

\section{PEMBAHASAN}

\section{Media sosial sebagai alat propaganda}

Propoganda politik sebagaimana yang terjadi di sosial media sengaja didesain para pengguna sosial media secara brutal. Menggunakan jejaring sosial untuk kepentingan politik adalah kampanye propaganda para tokoh politik disaat pemilihan umum, baik kepala legislatif maupun eksekutif. Disaat itulah berita yang disiarkan di jejaring sosial belum bisa dipastikan kebenarannya. Prilaku seperti ini disebut oleh para aktivis media sosial sebagai braggadocian behavior (perilaku pembual dan pembohong).

Sejalan dengan Peter G.W. Keen dan Stephen Haag (1996), Seperangkat alat yang digunakan untuk membantu seseorang bekerja itu disebut teknologi. Oleh sebab itu media sosial sebagai produk teknologi dijadikan alat bantu untuk mempermudah keinginan manusia mensosialisasikan kepentingannya di media sosial. Pada saat seseorang ketergantungan pada media sosial, maka media sosial itu akan mempengaruhi bahkan merekayasa manusia itu sendiri. Karena teknologi memberikan akses kemudahan atas keinginan manusia, maka tanpa disadari kehidupan manusia sudah mengalami ketergantungan pada teknologi (khususnya media sosial) yang lambat laun akan menjadi racun membius dan mengendalikan pikiran manusia.

Propoganda politik acapkali terjadi di media sosial. Begitu juga ketika media Barat, mengisukan bahwa faham-faham radikal berasal dari ajaran Islam, walaupun sebenarnya itu berita bohong di desain untuk menarik simpati dunia untuk bersamasama membenci Islam (Islamophobia). Sehingga, propaganda pada era media sosial ini (internet) penuh dengan tujuan-tujuan propokatif yang terselubung. Tanpa

\footnotetext{
${ }^{6}$ Nuruddin, Pengantar komunikasi massa, (Jakarta: Raja grafindo persada, 2011), hlm.116
} 
disadari masyarakat kita media baru seperti sosmed mampu merubah pandangan mereka bahkan dunia. Jejaring seperti halnya media sosial tidak lagi digunakan sesederhana biasanya, hanya sekedar transfer informasi. Namun sudah dimobilisasi sedemikian rupa untuk kepentingan propaganda. Bahkan masuk untuk merekonstruksi pola pikir manusia. Misalnya ketika mencuat Kasus Simulator SIM yang berbuntut panjang melibatkan Keopolisisian Republik Indonesia (POLRI) dan Komisi Pemberantas Korupsi (KPK). Ketika KPK ingin menguak isu penyelewengan dana pada Lembaga negara yang menangani proyek simulator SIM, Kita melihat ada dua kekuatan besar yang bersiteru yakni KPK dan Polri. Para pengguna sosmed banyak memberikan dukungan kepada lembaga Komisi Pemberantasan Korupsi, Itu semua atas dasar anggapan bahwa lembaga Kepolisian yang bertanggung jawab atas dana simulator itu sebagai musuh bersama. Kemarahan masyarakat tersebut disebabkan korupsi yang belum jelas duduk perkaranya (terlepas isu tersebut benar atau tidak) dilampiaskan dengan pembelaannya atau dukungan penuh kepada KPK. Terlihat jelas bahwa adanya mobilisasi sikap (pro dan kontra) di media sosial.

Kemudian, Media sosial dijadikan masyarakat sebagai alat pengawas atas kasus-kasus yang ada disekitarnya. Sebagai penyambung atau perpanjangan tangan rakyat. Fasilitas jejaring ini menjangkau wilayah yang tak terbatas, Disini mereka aktualisasikan pendapat dan dukungan mereka kepada publik. Sebuah Lembaga pemantau jejaring sosial bernama Political wave, menemukan dukungan yang sangat besar kepada KPK pada jejaring sosial seperti di twitter, youtobe, dan media berjejaring lainnya secara nyata. Political wave menginformasikan arus besar dari medsos yang mendukung KPK untuk menguak isu korupsi ditubuh POLRI.

Banyak tagar dan hashtag yang bertebaran mengisi laman-laman dijejaring sosial yang sangat populer pada waktu itu seperti, \#PresidenKemana, \#SaveKpk, \#TolakRUUHIP, \#SavePolri dan yang lainnya, serta akun artis-artis kerap juga memperbincangkan topic yang sama seperti antara lain @sudjiwotedjo, @lukmansardi, @melaniesubono, @ dedicorbuzier, @ pandji, @addiems. Belum lagi dari kalangan politisi murni atau bahkan para pakar tentunya lebih banyak lagi. Hal ini menandakan tingginya tingkat aspirasi dimedia sosial dibandingkan dengan aspirasi didunia nyata.

Media sosial merupakan media penghubung yang diminati banyak orang serta sangat penting (tidak bisa diabaikan) untuk menyalurkan wacana (pembicaraan publik). Melaui arena yang tanpa batas ini, berbagai tingkatan masyarakat mengaktualisasikan pilihan-pilihannya, sehingga demokrasi dapat berjalan dengan baik di masyarakat. Melalui arena public yang bebas (public sphere) memungkinkan terwujudnya opini publik yang media angkat kepermukaan.

Masyarakat yang mengerti benar hak dan kewajibannya (yang terdidik \& berpengetahuan) mendambakan media yang dapat mewakili aspirasinya namun lebih terjaga keamanannya (maksudnya aflikasi yang resmi dan terlindungi). Kebebasan public/Public sphere ini, awalnya terbentuk pada abad ke XVIII di Inggris ketika 
surat kabar pertama kali mulai menampilkan fungsi modernnya dengan menyakikan tidak hanya informasi, tetapi juga menyajikan opini, komentar \& kritik, fasilitas debat diantara kelas terdidik \& kelompok penguasa.

Seperti disinggung diatas, Media sosial sudah dikonsumsi oleh masyarakat luas dengan kepentingan yang beraneka ragam. Informasi yang disampaikan oleh media sosial dapat mempengaruhi persepsi di masyarakat. yang pada akhirnya akan membentuk opini di masyarakat. Bila hal ini terjadi, dan dibenturkan dengan kepentingan sosial di masyarakat, tentu dapat dikatakan media sosial menimbulkan masalah baru di masyarakat.

\section{Media Sosial Menjadikan Manusia Bersikap Individualis}

Teknologi membuat manusia menjadi individualis, karena manusia dimanjakan dengannya. Sosialisasi dan komunikasi sudah dibatasi dengan teknologi (dibatasi oleh sebuah layar). Kendatipun terjadi, komunikasi tidak terjadi tatap muka, melainkan telah digantikan dengan perantara alat-alat teknologi komunikasi modren dengan fitur aplikasi internet. Seorang konsumen misalnya, mereka akan dimanjakan dengan kecanggihan teknologi. Semua aktifitas dapat dilakukan via online hanya didalam kamar semua kegiatan aman terkendali. Ketika mengiginkan sesuatu mereka cukup membuka aplikasi internet melalui facebook, twitter, whatsapp, mereka sudah disuguhkan lapak lapak jualan sesuai dengan keinginan yang apabila telah cocok tinggal dipesan. Kemudian jika membutuhkan berita kita disuguhkan koran online yang senatiasa bisa dibaca kapan saja di melalui internet. Kita akan mengetahui seluruh kejadian disekitar kita bahkan berita dunia dalam waktu singkat tanpa harus bertemu.

Sesuai dengan perjalanan waktu dan Perkembangan zaman, Peradaban manusia selalu berkembang. Fitrah manusia untuk selalu meningkatkan kualitas hidup dan kehidupannya juga sejalan dengan peradaban. Peradaban yang tinggi mendorong usaha peningkatan hidup yang berkualitas, Contohnya dorongan untuk mendapatkan kemudahan dalam berbagai aktivitas kehidupan, dorongan untuk tampil dan dihormati dan sebagainyanya. Tuntutan untuk peningkatan kualitas kehidupan ini disebut dengan keinginan (wants), Keinginan ini menghasilkan tuntutan baru selain pemenuhan kebutuhan minimal syarat kehidupan, yakni tuntutan yang banyak berkaitan dengan informasi dan jasa yang dihasilkan oleh media.

Cohen seorang tokoh komunikasi menyatakan, "Media tidak mempengaruhi pemirsa atau pembaca bagaimana untuk berpikir, tetapi yang terjadi adalah media berhasil merubah mindset pembaca agar memikirkan apa yang perlu dipikirkan”. Sehingga dengan demikian, maka dapat dikatakan pengaruh media sosial sangat signifikan untuk sebuah perubahan pola fikir. Sosial media adalah situs yang digunakan untuk berinteraksi antara individu atau kelompok yang satu dengan individu atau kelompok lain dan berbasis online, dengan menggunakan teknologi komunikasi mobil (mobile networking) yang terhubung ke Internet atau jaringan 
yang memiliki kecepatan akses yang tinggi dengan tujuan untuk mempermudah komunikasi, mempengaruhi, dan berinteraksi secara individualis.

Muncul individualisme baru dalam kehidupan sehari- hari. Kota Jakarta penuh dengan mall, disatu tempat dapat kita jumpai dua atau tiga bahkan empat mall. Media massa adalah kawan kapitalisme global, sedangkan masyarakat konsumen sebagai ciptaan kapitalisme global akhirnya melahirkan individualisme baru seperti realitas sosial yang kita alami dalam kehidupan dewasa ini. Dalam hal ini jelas tampak bahwa revolusi media massa telah mengubah secara signifikan tatanan kehidupan manusia dimanapun berada termasuk di Indonesia. berdomisili dikotakota besar. Secara pesimis Jean Baudrillard meramalkan bahwa dunia saat ini sedang menuju kearah kehancuran dirinya sendiri (chatastrophe). ${ }^{7}$

Pemikiran Jean Baudrillard ini terdapat dalam tataran epistemologis yang memandang kehidupan masyarakat sebagai sebuah fenomena hipotetis. Padahal hidup ini kongkrit, kenyataannya sebagian masyarakat walau sudah terpikat seperti apapun oleh tayangan- tayangan iklan, masih ada yang memiliki kesadaran memilih dengan kebebasannya. Memang pemikiran Baudrillard amat cemerlang, namun pemikiran tersebut baru dapat dipandang dari sudut pandang umum tidak dari segi orang perorang. Maka sebenarnya jika kita memiliki pengetahuan yang memadai, kita masih tetap bisa menentukan diri kita sendiri melalui pilihan-pilihan etis yang berdasarkan pertimbangan-pertimbangan yang baik dan yang tidak. Setiap orang memiliki cara etis masing- masing sesuai keinginannya tanpa harus merugikan orang lain dan keluar dari tatanan yang sudah ada dimasyarakat sebagai mahluk sosial. ${ }^{8}$

\section{Media sosial sebagai ajang Promosi Iklan Spam}

Penggunaan media sosial secara umum menghubungkan jaringan-jaringan berbagai pihak yang menggunakan jejaring sosial. Teknologi baru ini memiliki kecepatan akses yang tinggi dan penerbitan dengan skala penyebaran yang luas membantu interaksi antara individu atau kelompok lainnya secara cepat. Masyarakat hari ini sedang euphoria di media sosial sehingga seluruh aktivitas kehidupannya selalu di upload dimedia sosial dan dapat dilihat oleh banyak orang. Media ini sudah merambah kesemua orang dengan beragam latar belakang dan berhubungan diruang yang sama yaitu ruang media sosial. Para pelaku ekonomi juga mau tidak mau harus melirik media baru ini supaya tidak ketinggalan apalagi konsumen sekarang lebih banyak dimedia sosial ketimbang di pasar. Di manapun tempatnya, semua lapisan mau tidak mau harus bersentuhan dengan media baru ini agar tidak ketinggalan informasi. Banyak kegiatan-kegiatan transaksi ekonomi terjadi di media sosial, Bahkan pendidikan juga hari sudah bertransformasi kedalam desain virtual.

\footnotetext{
${ }^{7}$ John Lehcte, 50 filusuf kontenporer dari strukturalisme sampai postmodernitas, (Yogyakarta: Kanisuis, 2001), hlm. 352.

8 Yasraf amir, Dunia yang dilipat; Tamasya Melampaui Batas-batas Kebudayaan (Bandung: Matahari, 2011), hlm.38.
} 
Jika anda pernah menerima pesan dijejaring sosial secara berulang-ulang dan menawarkan berbagai kemudahan dan kenyamanan hati-hati berarti anda sedang menerima konten spam. Dalam new media ini, informasi sampah sering kali muncul dalam status jual beli online. Dengan menawarkan harga yang murah, diluar harga pasar. Sehingga menghipnotis pembeli untuk segera kontak dengan penjual. Alhasil pembeli tersugesti dengan tipuan si penjual, dengan mengarahkan untuk mengirim uang via ATM. Dalam komunikasi pemasaran dan periklanan yang menggambarkan keinginan pemasangan iklan terhadap perkembangan perubahan perilaku konsumen yang menjadi target atau sasaran iklan, yaitu iklan diharapkan dapat mensugesti ingatan konsumen terhadap produk (Awaneress). Sehingga mendorong konsumen untuk memiliki minat membeli, kemudian memutuskan untuk membeli produk yang produsen tawarkan pada iklan dimedia sosial. Tanpa melibatkan target audience sesekali, dengan demikian Model ini hanya berjalan satu arah.

Kepentingan sosial (sosical interest) disisi lain adalah menyangkut masalah yang cukup luas, yang berkaitan dengan kepentingan sosial orang banyak, berupa hak dasar manusia, atau perlindungan terhadap hak asasi manusia.Sehubungan dengan hal tersebut, maka beberapa hal yang perlu diatur oleh negara berkaitan dengan media dan kepentingan sosial masyarakat, antaralain:Media dan Hak asasi manusia (The Media and Human Right). Media dan Hak Pribadi (The Media curiosity and Privasi). Kepentingan Media dan Masyarakat (The and Sodical Interest). Kepentingan dan Barang dan Jasa Publik (Public interest and the public good).

Ini menjadi ancaman para perlaku bisnis yang sedari awal menanamkan etika kejujuran. Dengan demikian maka pelaku usaha bisnis (termasuk bisnis media) berkepentingan agar apa yang disiarkan atau diberitakan oleh media dapat membuat iklim usaha menjadi lebih baik, atau paling tidak jangan merusak iklim usaha yang dianggap susah kondusif. Pemberitaan harus seimbang (antara yang positif yang positif dan negatif, yang pro dan kontra). Dengan demikian, maka berita yang disampaikan ke public tidak menimbulkan rasa pesimis ditengah masyarakat, yang mengakibat kondisi ekonomi yang sudah buruk, menjadi lebih buruk lagi disebabkan oleh iklan spam yang tidak bertanggung jawab.

Dalam rangka meningkatkan kepuasan konsumen dan kesejahteraan produsen dipasar media, maka produsen harus memperhatikan bentuk pasar yang bersaing sehat bukan pasar yang mendorong konsentrasi pasar oligopoli atau pasar monipoli. Karena dikhawatirkan munculnya kekuatan produsen media yang mengakumulasi pasar dan dapat memanipulasi kepentingan publik. Selaras dengan mekanisme pasar yang diharapkan pemodal media tersebut. Maka agenda pasar dijejaring sosial didesain semaunya oleh pemilik media bahkan sponsor-sponsornya. Demi kepentingan nasional pemerintah sehaarusnya mengatur lebih tegas tentang mekanisme pasar dijejaring sosial agar tidak banyak beredar spam yang nantinya merugikan masyarakat pengguna jejaring sosial. 
Pada umumnya ada tiga (3) model kepemilikan media yakni sebagai berikut:

1. Public services yaitu sistem layanan publik yang dimiliki oleh negara yang penggunaanya diatur untuk tujuan institusi publik demi menggapai tujuan bernegara.

2. Commercial Model yaitu sistem komersil, model media seperti ini biasanya dimiliki swasta dan fungsinya didni sebesar-besarnya mencari keuntungan.

3. Commnuity Services yaitu media komunitas yang dimiliki komunitas masyarakat tertentu. Media disini digunakan untuk mengcover kepentingan yang tergabung dalam komunitas.

Tidak dipungkiri lagi hari ini bisnis melalui jejaring sosial lagi berkembang pesat (naik daun), sangking populernya media ini tanpa kita sadari banyak beredar spam (pesan sampah) yang sangat berbahaya karena dapat merugikan pengguna jejaring secara materi namun tidak ada pertanggung jawabannya. Maka pasar dimedia yang seharusnya menguntungkan bagi pelaku bisnis yang jujur tapi akibat oknum penggiat spam atau bisnis curang, lambat laun tingkat kepercayaan pasar dijejaring sosial semakin berkurang.

\section{PENUTUP}

Pergeseran Desain Komunikasi di Media sosial dalam temuan penelitian ini adalah Propoganda. Ia merupakan salah satu indikator nyata bagaimana media sosial didesain para pengguna media sosial secara tidak benar. Idealnya sejalan dengan Haag dan peter keen, bahwa teknologi itu untuk membantu manusia. Penggunaan teknologi komunikasi dijejaring sosial secara tidak benar hanya akan menjadi racun pembius yang mencemari pikiran dan tindakan manusia.Media Sosial Menjadikan Manusia Bersikap Individualis. Artinya interaksi sosial hanya terjadi di dunia maya dan mengurangi kuantitas komunikasi tatap muka secara langsung. Aktivitas melalui media baru ini bisa terjadi dimana saja dan kapan saja dalam jaringan aplikasi media sosial. Media tidak mempengaruhi pemirsa atau pembaca bagaimana untuk berpikir, tetapi yang terjadi adalah media berhasil merubah cara pandangnya.

Euphoria dalam menggunakan media sosial sering kali menjebak pengguna media sosial untuk mengkonsumsi iklan spam, informasi sampah sering kali muncul dalam status jual beli online. Dengan menawarkan harga yang murah, diluar harga pasar. Sehingga menghipnotis pembeli untuk segera kontak dengan penjual. Alhasil pembeli tersugesti dengan tipuan si penjual, dengan mengarahkan untuk mengirim uang via ATM. Temuan di atas sejalan dengan teori jarum hipodemik (hypodermic theory) atau teori peluru (bullet theory). Sebagamana pernah dikatakan Jason dan Anne Hill (1997) bahwa teori jarum hipodemik adalah efek langsung pesan yang “disuntikkan" ke dalam ketidaksadaran audience. Dengan kata lain. apa pun pesan yang disebarkan oleh media, maka akan diterima begitu saja oleh masyarakat. 


\section{DAFTAR PUSTAKA}

Amir Piliang, Yasraf. 2011, Dunia Yang Dilipat; Tamasya Melampaui Batas-batas Kebudayaan, Bandung: Matahari.

B. Aubrey Fisher. Teori-teori Komunikasi (Perspectives on Human Communication), Bandung, Remadja Karya, 1986.

Devito, Joseph A. 2011, Komunikasi Antar Manusia, Jakarta: Kharisma.

Fraenkel and Wallen. 2007. How to Disign and Evaluate Research in Education, New york: McGraw-Hill.

Haag, Stephen dan Peter G.W. Keen. 1996. Information_Technology: Tomorrow's Advantage Today. New York: McGraw Hill College.

Haenlein, Michael dan Andreas Kaplan. 2010. User of the World, Unite! The Challenges and Oppurtunities of Sosial Media. Bussiness Horizons.

lechte, John. 2001. 50 Filsuf Kontemporer dari Strukturalisme Sampai Postmodernitas, Yogyakarta: Kanisuis

Littejohn, Stephan W, dkk. 2011. Teori Komunikasi Edisi 9, Jakarta: Salemba Humanika.

McQuail, D. 2003. Teori Komunikasi Massa, Jakarta: Penerbit Erlangga.

Nuruddin. 2011. Pengantar Komunikasi Massa, Jakarta: Raja grafindo persada.

Puntoadi, Danis. 2011. Menciptakan Penjualan melalui Social Media, Jakarta: PT. Elex Media Komputindo.

Qualman, Erik. 2010. Socialnomics, How Social Media Transforms The Way We Live and DoBusiness. Burlington: Awareness.

Sutopo. 2002. Metodologi Penelitian Kualitatif. Surakarta: UNS Press. 